\title{
Synthesis and Spectral Characterization of Novel Pyridotriazolo-, Pyridothiazolo-, Pyridotetrazolopyrimidines and Pyridopyrimidotriazepine Derivatives for Potential Pharmacological Activities
}

\author{
Mahmoud R. Mahmoud ${ }^{1}$, Manal M. El-Shahawi ${ }^{1}$, Fatma S.M. Abu El-Azm ${ }^{1, *}$, Samira E. Farahat ${ }^{2}$ \\ ${ }^{1}$ Chemistry Department, Faculty of Science, Ain Shams University, Abbassia 11566, Cairo, Egypt \\ ${ }^{2}$ Chemistry Department, Faculty of Science, $7^{\text {th }}$ of April University, Gharian, Libye
}

\begin{abstract}
Number of pyridotriazolo-, pyridothiazolo-, pyridotetrazolopyrimidines and pyrido-pyrimidotriazepine derivatives were prepared using the readily obtainable starting material pyrido[2,3-d]pyrimidinthione ${ }^{1}$ and its hydrazino derivative. The antimicrobial screening of selected synthesized compounds was done using the agar diffusion assay. The IR, ${ }^{1} \mathrm{H}$ NMR and mass spectra of the synthesized compounds were investigated.
\end{abstract}

Keywords Fused Pyrimidines, One Carbon Donor, Fused [1,2,4]Triazepine

\section{Introduction}

$[1,2,4]$ Triazoles represent a class of heterocyclic compounds of significant importance in a agriculture and medicine $^{2,3}$. They used in metalloorganic chemistry as polyfunctional lignads ${ }^{4}$. They also exhibit a broad spectrum of biological activity. ${ }^{5}$ Pronounced pharmacological and biological activities are also intrinsic for pyridopyrimidines ${ }^{6-10}$. This stimulated us to combine the above pharmacophoric fragments is a single molecule and to continue our previous work for synthesis of novel heterocycles. ${ }^{11-21}$ Here, we used the easy obtainable substituted chalcone and 6-aminothiouracil for synthesis of 5-(4-methylphenyl)-7-phenyl-2-thioxo-2,3dihydropyrido[2,3-d]pyrimidin-4(3H)one ${ }^{1} 1$.

\section{Results and Discussions}

6-Aminothiouracil reacted with 3-(4-methoxyphenyl)1-phenylprop-2-enone in equimolar portion in the presence of catalytic amount of piperidine in ethanol to afford the adduct 2,3-dihydro-5-(4-methoxyphenyl)-7-phenyl-2-thioxo pyrido[2,3-d]pyrimidin- $4(1 \mathrm{H})$-one 1 . The formation of 1 is assumed to proceed via Michael addition of aminothiouracil

* Corresponding author:

ftmsaber@yahoo.com (Fatma Abu El-Azm)

Published online at http://journal.sapub.org/ajoc

Copyright (C) 2011 Scientific \& Academic Publishing. All Rights Reserved
$\mathrm{C}-5$ to the activated double bond in prop-2-enone derivative, followed by1,6-exo-trig cyclization. ${ }^{1} \mathrm{H}$ NMR spectrum of 1 [DMSO- $\mathrm{d}_{6}$ ] revealed the signals at $\delta(\mathrm{ppm}): 13.0(\mathrm{~s}, 1 \mathrm{H}, \mathrm{NH}$, exchangeable with $\left.\mathrm{D}_{2} \mathrm{O}\right), 12.3(\mathrm{~s}, 1 \mathrm{H}, \mathrm{NH}$, exchangeable with $\left.\mathrm{D}_{2} \mathrm{O}\right), 8.4\left(\mathrm{~s}, 1 \mathrm{H}, \mathrm{C}_{6}-\mathrm{H}\right), 8.29-6.9\left(\mathrm{~m}, 9 \mathrm{H}_{\text {arom. }}\right)$ and $3.7(\mathrm{~s}$, $3 \mathrm{H}, \mathrm{OMe})$. Moreover, the mass spectrum show fragmentation pattern which completely in accord with the proposed structure 1.

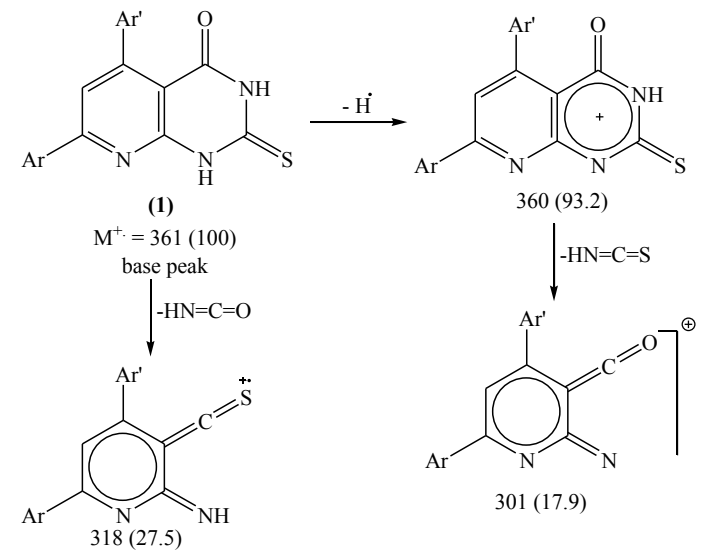

EI-MS fragmentation of compound 1

The reaction of pyrido[2,3-d]pyrimidine-2-thione derivative with ethyl chloroacetate was claimed to afford the thioacetic ester derivative $2 .{ }^{22}$ Here in, refluxing 1 with ethyl chloroacetate in n-butanol in presence of anhydrous sodium acetate yielded 2-carboxymethylthio-5-(4-methoxyphenyl) -7-phenyl-3H,4H-pyrido[2,3-d]pyrimidin-4(3H)one 2. 
(Scheme 1) The structure features of 2 was elucidated according to the following arguments: i- The IR spectrum devoid $v_{\mathrm{CO}}$ (ester) but retained $v_{\mathrm{CO}}$ (acid) at $1698 \mathrm{~cm}^{-1}$ together with broad absorption band for $-\mathrm{OH}$ group centered at $3446 \mathrm{~cm}^{-1}$. ii- The highest recorded peak in the mass spectrum at $\mathrm{m} / \mathrm{z}=419(100)$ which attributable for the molecular ion and the base peak. (C.f Exp.) iii- Compound 2 easily soluble in sodium bicarbonate solution. iv- Furthermore, ${ }^{1} \mathrm{H}$ NMR spectrum show down field signal attributable for carboxylic acid group at $\delta 11.3 \mathrm{ppm}$ together with singlet at $\delta$ $3.9 \mathrm{ppm}$ integrated for $2 \mathrm{H}\left(\mathrm{CH}_{2} \mathrm{COOH}\right)$.

Independent chemical proof for compound 2 seemed necessary, thus, when 2 was refluxed with freshly distilled acetic anhydride afforded pyrido [2,3-d] thiazolo [3,2-a] pyrimidine derivative 3 . Compound 3 was obtained in fairly good yield by stirring compound 1 with chloroacetyl chloride in pyridine for one hour. Ethylation of 1 using ethyl iodide in ethanol in the presence of fused sodium acetate yielded the S-alkylated product 4 . The microanalysis and mass spectrum of 4 indicates incorporation of one mole of ethyl iodide in the reaction product. EI-MS fragmentation show the correct molecular ion peak at $\mathrm{m} / \mathrm{z}=389(18.1 \%)$ together with the base peak at $\mathrm{m} / \mathrm{z}=361(100 \%)$ corresponding to the radical cation $\left[\mathrm{M}-\mathrm{C}_{2} \mathrm{H}_{4}\right]$. Moreover, the ${ }^{1} \mathrm{H}$ NMR spectrum show the signals attributable for the S-ethyl group at $\delta 3.15 \mathrm{ppm}$ as quartet integrated for $2 \mathrm{H}$ and $\delta 1.36$ ppm as triplet integrated for $3 \mathrm{H}$. Hydrazinloysis of pyridopyrimidin-2-thione 1 with hydrazine hydrate $(80 \%)$ in boiling ethanol afforded the sulfur free compound 5 (yield $=39.6 \%$ ). Compound 5 which identified as 2-hydrazino-5-(4-methoxyphenyl)-7-phenyl-4-oxo-3H,4H-p yrido [2,3-d] pyrimidine could be obtained in fairly good yield $(56.6 \%)$ via nucleophilic displacement of thioethyl group with hydrazine in boiling ethanol. (Scheme 1)

The formation of 5 could be visualized as shown in scheme 2.

The structure 5 deduced from the satisfactory IR, ${ }^{1} \mathrm{H}$ NMR and MS spectra. The highest recorded $\mathrm{m} / \mathrm{z}$ value at $\mathrm{m} / \mathrm{z}=359$ $(100 \%)$ attributable for the molecular ion peak which is the base peak.<smiles>CCSc1nc2nc([Al])cc([AlH2])c2c(=O)[nH]1</smiles>

(4)<smiles>Nc1cc([Al])c2c(=O)n(CC#CC3CCCC3)c(N)nc2n1</smiles>

(5)

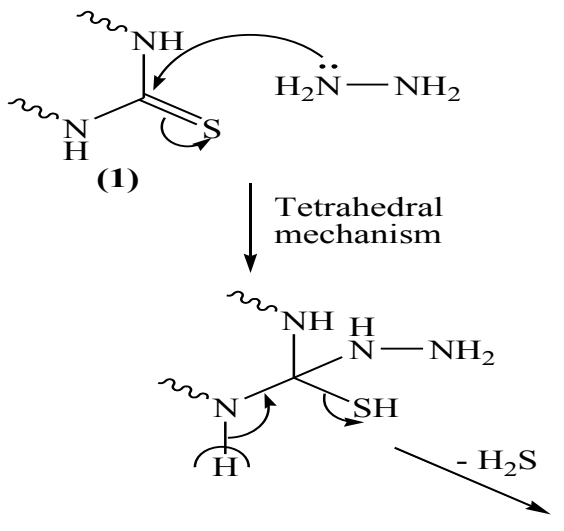

(1) $\mathrm{Ar}=\mathrm{C}_{6} \mathrm{H}_{5}$ $\mathrm{Ar}^{\prime}=\mathrm{C}_{6} \mathrm{H}_{4} \mathrm{OMe}-4$

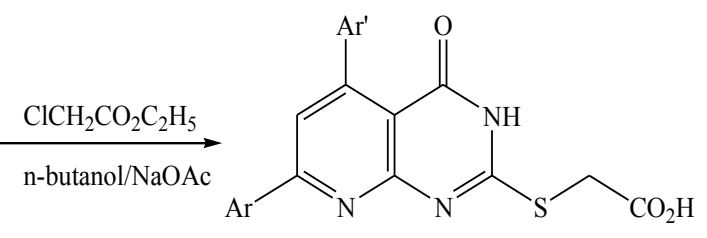

(2)<smiles>O=C1CSc2nccc(=O)n21</smiles>

(3)

Scheme 1

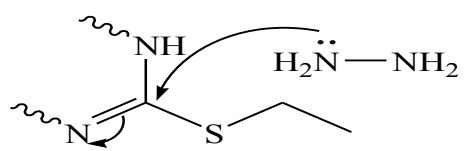

(4)<smiles>CCSCC(NC)(NC)NN</smiles><smiles>CN=C(N)NN</smiles>

(5)

Scheme 2 

The hydrazino derivative 5 was used as the key intermediate for synthesis of polyheterocyclic compounds. A rapid, efficient and clean exclusive synthesis of pyrido $[1,2,4]$ triazolo[4,3-a]pyrimidines from the reaction of 5 with one carbon donors such as triethylorthoformate, ethyl chloroformate, phenyl isothiocyanate and acetic anhydride. Thus, compound 5 when treated with triethylorthoformate in the presence of freshly distilled acetic anhydride afforded a product with molecular formula $\mathrm{C}_{21} \mathrm{H}_{15} \mathrm{~N}_{5} \mathrm{O}_{2}\left[\mathrm{M}^{+}=369\right.$ $(100 \%)]$. Two isomeric pyridotriazolopyrimidine derivatives 6 and 7 seemed possible. Structure 6 was established for this product from the IR spectrum which revealed a stretching absorption bands for the carbonyl group at $1714 \mathrm{~cm}^{-1}$ (higher value than that of the hydrazino derivative 5 which indicates the absence of enolic form and eliminate structure 7. Another clue for the structure 6 is forthcoming from the study of ${ }^{1} \mathrm{H}-\mathrm{NMR}$ and mass spectra (C.f. Exp.)

6-(4-Methoxyphenyl)-8-phenyl-1H,2H-pyrido[2,3-d]-1,2, 4-triazolo [4,3-a] pyrimidin-3,5-dione 8 was obtained in fairly good yield upon treatment of compound 5 with ethyl chloroformate in boiling acetic acid. (Scheme 3)

The structure 8 was evidenced by spectroscopic data. Thus, the IR spectrum displayed $v_{\mathrm{NH}}(\mathrm{br})$ centered at $3256 \mathrm{~cm}^{-1}$ and two carbonyl stretching absorption bands at $1713,1700 \mathrm{~cm}^{-1}$. The highest recorded $\mathrm{m} / \mathrm{z}$ value in the mass spectrum represents the molecular ion and the base peak $[\mathrm{M}=385$ (100)]. Moreover, ${ }^{1} \mathrm{H}$ NMR spectrum supports the assigned structure (C.f. Exp.).

The reaction of the hydrazino derivative with phenyl isothiocyanate was reported to give the N-phenyl thiosemicarbazide derivative. Here in, treatment of compound 5 with phenyl isothiocyanate in refluxing pyridine afforded 6-(4-methoxyphenyl)-8-phenyl-3-thioxo-1H,2H-pyrido[2,3d]1,2,4-triazolo[4,3-a]pyrimidin-5-one 9. The IR spectrum of 9 exhibited the stretching absorption bands at 3381 (br.), 1676 and $1246 \mathrm{~cm}^{-1}$ attributable for $\mathrm{NH}, \mathrm{CO}$ and $\mathrm{C}=\mathrm{S}$ groups, respectively. Moreover, the mass spectrum devoid the molecular ion peak and the highest recorded peak at $\mathrm{m} / \mathrm{z}=369$ $(100 \%)$ corresponds to the radical cation M-S and represent the base peak.

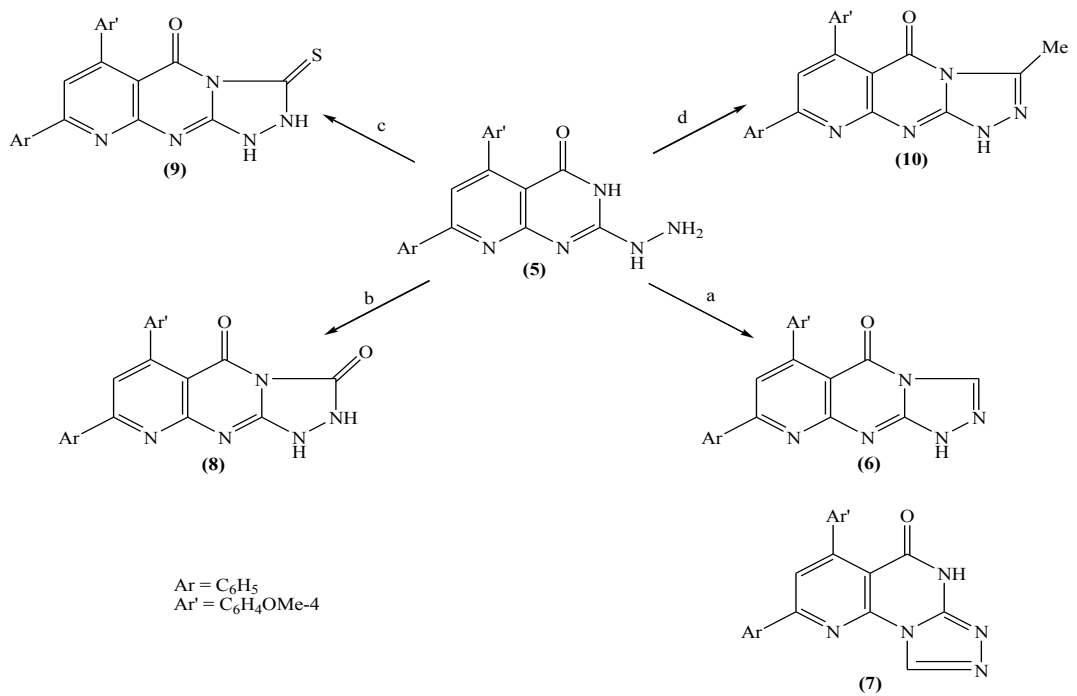

Scheme 3. a, $\mathrm{CH}(\mathrm{OEt})_{3} / \mathrm{Ac}_{2} \mathrm{O} ; \mathrm{b}, \mathrm{ClCO}_{2} \mathrm{Et} / \mathrm{AcOH} ; \mathrm{c}, \mathrm{PhNCS} / \mathrm{py}$; d, $\mathrm{Ac}_{2} \mathrm{O}$

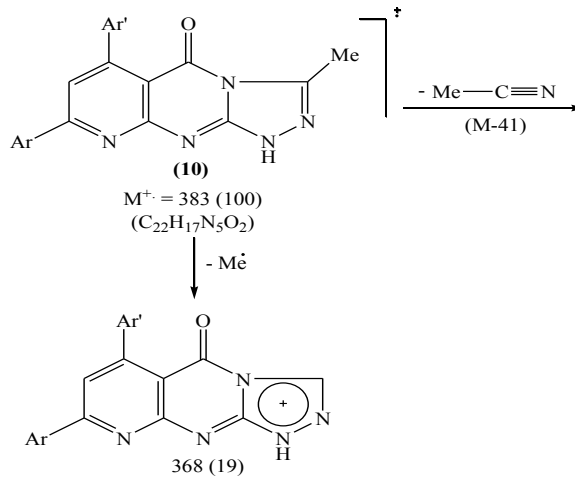<smiles></smiles><smiles></smiles> 
Ample evidence for the structure 9 is forthcoming from ${ }^{1} \mathrm{H}$ NMR analysis which completely consistent with the proposed structure (C.f. Exp.). Treatment of compound 5 with freshly distilled acetic anhydride yielded 3-methyl-8-phenyl -6-(4-methoxyphenyl)-1H,2H-pyrido[2,3-d]1,2,4-triazolol[4 ,3-a]pyrimidin-5-one 10 whose structure was deduced from the correct analytical and spectroscopic data. The IR spectrum of 10 displayed one absorption band for the carbonyl group at $1699 \mathrm{~cm}^{-1}$ and ${ }^{1} \mathrm{H}$ NMR spectrum [DMSO-d $\mathrm{d}_{6}$ ] revealed signals at $\delta(\mathrm{ppm}) 8.6\left(\mathrm{~s}, 1 \mathrm{H}, \mathrm{C}_{7}-\mathrm{H}\right), 8.1-7.2(\mathrm{~m}$, $9 \mathrm{H}_{\text {arom. }}$ ), 7.1 (br.s, $1 \mathrm{H}, \mathrm{NH}$, exchangeable with $\mathrm{D}_{2} \mathrm{O}$ ), 3.87 (s, $3 \mathrm{H}, \mathrm{OMe})$ and $2.9(\mathrm{~s}, 3 \mathrm{H}, \mathrm{Me})$. Furthermore, the EI-MS of 10 show the correct molecular ion peak at $\mathrm{m} / \mathrm{z}=383(100 \%)$ which upon loss of acetonitrile molecule afforded the radical cation at $\mathrm{m} / \mathrm{z}=342(22.3 \%)$.

The formation of compounds $8-10$ is assumed to proceed via nucleophilic addition of the hydrazino nitrogen nucleophile to the activated carbonyl and thiocarbonyl group via tetrahedral mechanism followed by 1,5-exo-trig cyclization. (Scheme 4)

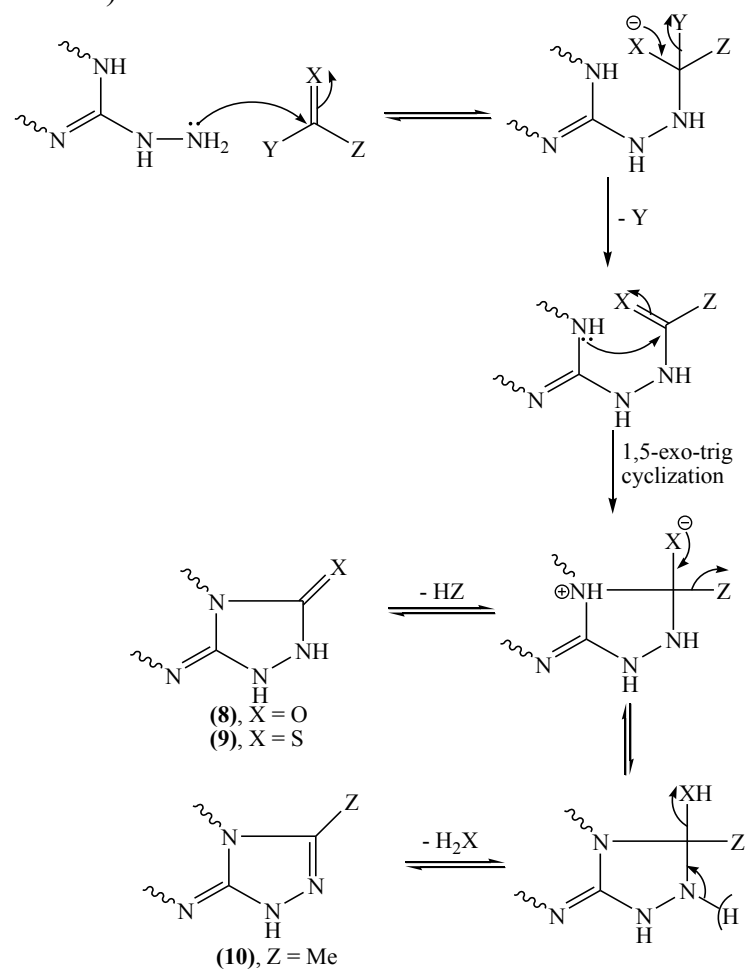

Scheme 4. Synthesis of pyridotriazolopyrimidines 8, 9, 10

In the context, the reaction of hydrazino derivative with 1,3-dicarbonyl compound was claimed to afford the pyrazole derivatives. When compound 5 reacted with dicarbonyl compounds namely, pentan-2,4-dione and/or 1-phenyl butan-1,3-dione yielded pyrido [2,3-d] pyrimido [2,1-c] 1,2,4-triazepine derivative 11a,b. (Scheme 5)

The IR spectra of 11a,b show sharp absorption bands for $\mathrm{NH}$ at ca. $3368 \mathrm{~cm}^{-1}, \mathrm{C}=\mathrm{O}$ at $1697 \mathrm{~cm}^{-1}$ and $\mathrm{C}=\mathrm{N}$ at 1628 $\mathrm{cm}^{-1}$. ${ }^{1} \mathrm{H}$ NMR spectrum of $11 \mathrm{a}$ exhibit signals at $\delta(\mathrm{ppm})$ $6.09\left(\mathrm{~s}, 1 \mathrm{H}, \mathrm{C}_{4}-\mathrm{H}\right), 3.8$ (s, 3H, OMe), 2.9 (s, 3H, $\left.\mathrm{C}_{3}-\mathrm{Me}\right)$, and $2.27\left(\mathrm{~s}, 3 \mathrm{H}, \mathrm{C}_{5}-\mathrm{Me}\right)$. Full analysis for the mass spectrum of $11 \mathrm{a}$ show the correct molecular ion peak at $\mathrm{m} / \mathrm{z}=$
$423(97.2 \%)$ which loss hydrogen radical to give the cation $\mathrm{M}-1$ at $\mathrm{m} / \mathrm{z}=422(100 \%)$.

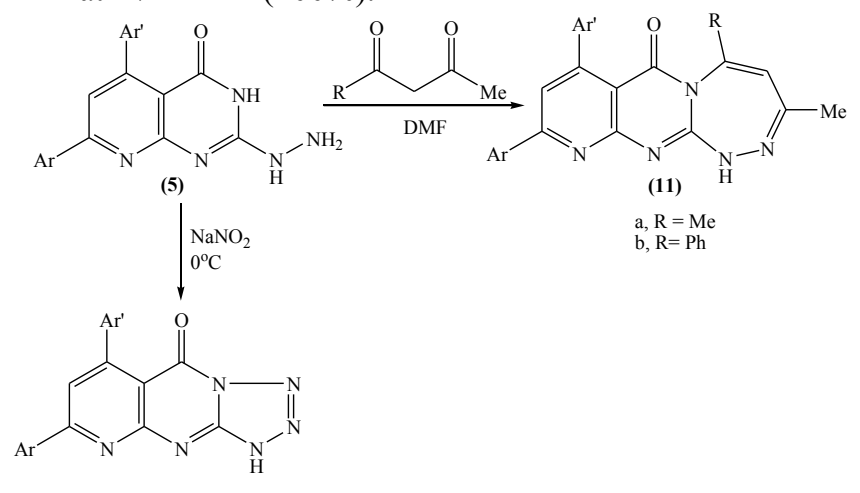

(12)

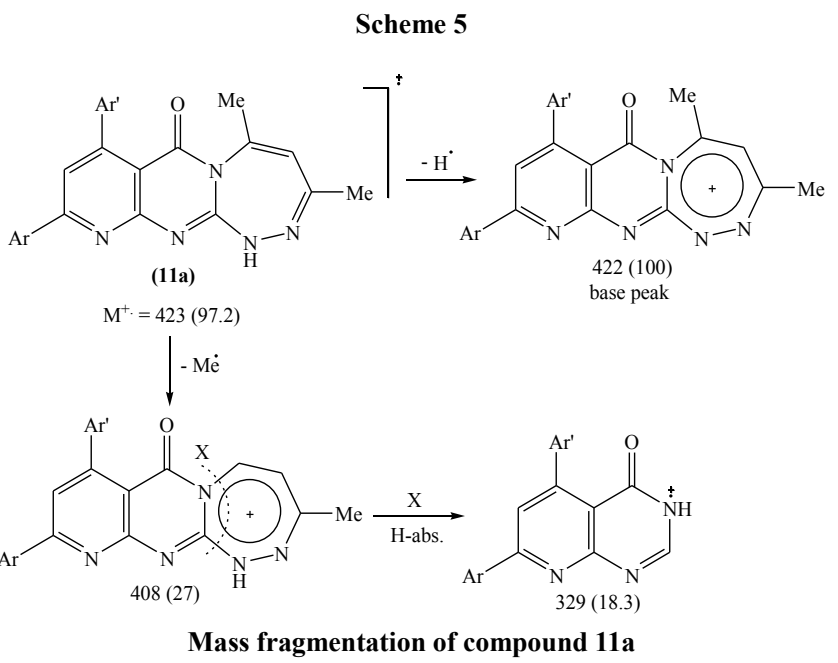

The structure $11 \mathrm{~b}$ was confirmed by analysis of IR, ${ }^{1} \mathrm{HNMR}$ and mass spectrum which were completely in accord with the assigned structure. (C.f. Exp.)

When solution of 5 in dilute hydrochloric acid was stirred with sodium nitrite solution at $0^{\circ} \mathrm{C}$ yielded the pyridotetrazolo pyrimidine derivative 12 whose structure was deduced from the study of IR and mass spectrum (C.f. Exp.).

\section{Biological Investigations}

\subsection{Antimicrobial activity}

The antimicrobial screening of all the synthesized compounds was done using the agar diffusion assay. This screening was performed against the Gram-negative bacteria, Escherichia coli ATCC 10536 and Gram-positive bacteria, Staphylococcus aurous ATCC 06538 in addition to the pathogenic fungi Candida albicans ATCC 1023 and Aspergilus flavus. A moderate activity was observed with compounds $2,3,6,8,10,11 \mathrm{a}, 11 \mathrm{~b}$ and 12 which proved to possess marked activity against E. coli, S. aurous, and C. albicans. The inhibitory concentration was determined for each of the active compounds along with Ampicillin, Streptomycin, and Nystatin as positive controls. No activity was detected for all the synthesized compounds towards Aspergilus flavus. Results are shown in Table 1. 
M. R. Mahmoud et al.: Synthesis and Spectral Characterization of Novel Pyridotriazolo-, Pyridothiazolo-, Pyridotetrazolopyrimidines and Pyridopyrimidotriazepine Derivatives for Potential Pharmacological Activities

Table 1. Antimicrobial screening results of the tested compounds at $1000 \mathrm{~g} / \mathrm{ml}$

\begin{tabular}{|c|c|c|c|}
\hline Compd. No. & E. coli & S. aurous & C. albicans \\
\hline $\mathbf{1}$ & 0.0 & 0.0 & 0.0 \\
\hline $\mathbf{2}$ & 15 & 14 & 14 \\
\hline $\mathbf{3}$ & 14 & 13 & 15 \\
\hline $\mathbf{4}$ & 0.0 & 0.0 & 0.0 \\
\hline $\mathbf{6}$ & 14 & 12 & 11 \\
\hline $\mathbf{8}$ & 15 & 14 & 15 \\
\hline $\mathbf{1 0}$ & 14 & 15 & 16 \\
\hline $\mathbf{1 1 a}$ & 13 & 13 & 14 \\
\hline $\mathbf{1 1 b}$ & 15 & 13 & 15 \\
\hline $\mathbf{1 2}$ & 16 & 17 & 18 \\
\hline Ampicillin & 0.0 & 22 & 0.0 \\
\hline Streptomycin & 20 & 21 & 0.0 \\
\hline Nystatin & 0.0 & 0.0 & 22 \\
\hline
\end{tabular}

No activity (0.0), (inhibition zone $<7 \mathrm{~mm}$ ), weak activity (7-10 $\mathrm{mm})$, moderate activity $(11-15 \mathrm{~mm})$, strong activity $(>15 \mathrm{~mm})$. Solvent: DMSO (6 mm)

\section{Experimental}

All melting points were taken on Griffin and Geory melting point apparatus and are uncorrected. IR spectra were recorded on Pye Unicam SP 1200 spectrophotometer using $\mathrm{KBr}$ Wafer technique. ${ }^{1} \mathrm{H}-\mathrm{NMR}$ spectra were determined on a Varian Gemini $300 \mathrm{MHz}$ using TMS as internal standard (chemical shifts in $\delta$-scale). The mass spectra were determined using HP model MS-5988 at electron energy 70 $\mathrm{eV}$. Elemental analyses were carried out at the microanalytical unit, faculty of science, Cairo University by using Perkin-Elmer 2400 CHN elemental analyzer.

5-(4-Methoxyphenyl)-7-phenyl-2-thioxo-2,3-dihydropyrido [2,3-d]pyrimidin-4(3H)-one 1

A mixture of $1(1.43 \mathrm{~g}, 0.01 \mathrm{~mol})$ and $2(2.4 \mathrm{~g}, 0.01 \mathrm{~mol})$ was refluxed in $(50 \mathrm{ml})$ absolute ethanol with $(2 \mathrm{ml})$ piperidine for 4 hours. The reaction mixture was allowed to cool, and then poured into ice hydrochloric acid. The yellow product deposited was filtered off, dried and then recrystallized from dioxane to give 1 as yellow crystals, m.p. $>300^{\circ} \mathrm{C}$ (yield 66\%). IR $\left(v \mathrm{~cm}^{-1}\right)$ : 3398, 3293(2NH), $1697(\mathrm{C}=\mathrm{O})$, $1173(\mathrm{C}=\mathrm{S}) .{ }^{1} \mathrm{HNMR}\left(\mathrm{DMSO}_{\mathrm{d}}\right)$ ): $\delta 13(\mathrm{~s}, 1 \mathrm{H}, \mathrm{NH}$, broad exchangeable with $\left.\mathrm{D}_{2} \mathrm{O}\right), 12.3(\mathrm{~s}, 1 \mathrm{H}, \mathrm{NH}$, broad exchangeable with $\left.\mathrm{D}_{2} \mathrm{O}\right), 8.4\left(\mathrm{~s}, 1 \mathrm{H}, \mathrm{C}_{6}-\mathrm{H}\right), 8.29-6.9\left(\mathrm{~m}, 9 \mathrm{H}_{\text {arom }}\right)$, 3.7 (s, 3H, OMe). MS m/z (\%): $361\left(\mathrm{M}^{+}, 100\right), 360$ (93), 301 (8), 318 (8). Anal. Calcd. For $\mathrm{C}_{20} \mathrm{H}_{15} \mathrm{~N}_{3} \mathrm{O}_{2} \mathrm{~S}$ (361): C, 66.48; H, 4.16; N, 11.63; S, 8.86, Found: C, 66.62; H, 3.95; $\mathrm{N}, 11.42 ; \mathrm{S}, 9.02$.

2-Carboxymethylthio-5-(4-methoxyphenyl)-7-phenyl pyrido[2,3-d]-pyrimidin-4(3H)-one 2

Compound $1(1.8 \mathrm{~g}, 0.005 \mathrm{~mol})$ was refluxed with ethyl chloroacetate $(0.74 \mathrm{~g}, 0.006 \mathrm{~mol})$ in $\mathrm{n}$-butanol in the presence of anhydrous sodium acetate $(2.7 \mathrm{~g})$ for 10 hours. The separated solid was washed with warm water several times and then filtered off, dried and recrystallized from ethanol to give 2 as brown crystals; m.p. $210-211^{\circ} \mathrm{C}$ (yield $65 \%$ ). IR $\left(v \mathrm{~cm}^{-1}\right): 3452$ (broad $\left.-\mathrm{OH}\right), 1701(\mathrm{C}=\mathrm{O}$, acid), 1687 $(\mathrm{C}=\mathrm{O}$, imide). ${ }^{1} \mathrm{HNMR}\left(\mathrm{DMSO}^{-} \mathrm{d}_{6}\right): \delta 12.6(\mathrm{~s}, 1 \mathrm{H}, \mathrm{NH}$, broad ex- changeable with $\mathrm{D}_{2} \mathrm{O}$ ), 11.3 (br.s, $1 \mathrm{H}, \mathrm{COOH}$, exchangeable with $\left.\mathrm{D}_{2} \mathrm{O}\right), 8.7\left(\mathrm{~s}, 1 \mathrm{H}, \mathrm{C}_{6}-\mathrm{H}\right), 8.3-7.1\left(\mathrm{~m}, 9 \mathrm{H}_{\text {arom }}\right), 3.9(\mathrm{~s}, 2 \mathrm{H}$, $\left.\mathrm{CH}_{2} \mathrm{COOH}\right), 3.9$ (s, 3H, OMe). MS m/z (\%): $419\left(\mathrm{M}^{+}, 82\right)$, $401\left(\mathrm{M}^{+}-\mathrm{H}_{2} \mathrm{O}, 17\right), 391$ (56), 77 (74). Anal. Calcd. For $\mathrm{C}_{22} \mathrm{H}_{17} \mathrm{~N}_{3} \mathrm{O}_{4} \mathrm{~S}$ (419): C, 63.01; H, 4.06; N, 10.02; S, 7.63, Found: C, 63.23; H, 3.90; N, 10.25; S, 7.45.

3,5-Dioxo-6-(4-methoxyphenyl)-8-phenyl-2H,3H-pyrido

2,3-d] thiazolo[3,2-a] pyrimidine 3

Method 1

Compound $2(1 \mathrm{~g}, 0.002 \mathrm{~mol})$ was refluxed with freshly distilled acetic anhydride $(10 \mathrm{ml})$ for 3 hours. The reaction mixture was allowed to cool, and then poured into ice/water and left overnight in the refrigerator. The dark green precipitate was filtered off, washed several times with water, dried and then recrystallized from methanol to give 3 as pale green crystals m.p. $250-251^{\circ} \mathrm{C}$ (yield $49 \%$ ). IR $\left(\mathrm{v} \mathrm{cm}^{-1}\right)$; $1670,1682(2 \mathrm{C}=\mathrm{O}) .{ }^{1} \mathrm{HNMR}\left(\mathrm{DMSO}_{\mathrm{d}}\right): \delta 8.7(\mathrm{~s}, 1 \mathrm{H}$, $\left.\mathrm{C}_{7}-\mathrm{H}\right), 8.3-7.7\left(\mathrm{~m}, 9 \mathrm{H}_{\text {arom }}\right), 4.1\left(\mathrm{~s}, 2 \mathrm{H}, \mathrm{SCH}_{2} \mathrm{CO}\right), 3.9(\mathrm{~s}, 3 \mathrm{H}$, $\mathrm{OMe})$. MS m/z (\%): $401\left(\mathrm{M}^{+}, 12\right), 360(100)$. Anal. Calcd. For $\mathrm{C}_{22} \mathrm{H}_{15} \mathrm{~N}_{3} \mathrm{O}_{3} \mathrm{~S}$ (401): C, 65.84; H, 3.74; N, 10.47; S, 7.98, Found: C, 66.00; H, 3.61; N, 10.28; S, 8.11.

Method 2

To a stirred solution of compound $1(1.44 \mathrm{~g}, 0.004 \mathrm{~mol})$ in $20 \mathrm{ml}$ pyridine, the chloroacetyl chloride $(0.44 \mathrm{ml}, 0.004$ mol) was added dropwise over a period of $10 \mathrm{~min}$., then the reaction mixture was refluxed on water bath for 1 hour. The reaction mixture was poured into ice cold acetic acid and the solid deposited was filtered off, washed several times with light petroleum ether, dried and then recrysytallized from methanol to give 3 (yield $72 \%$ ).

2-Ethylthio-5-(4-methoxyphenyl)-7-phenylpyrido[2,3-d]

pyrimidin- $4(3 \mathrm{H})$-one 4

A mixture of $1(3 \mathrm{~g}, 0.008 \mathrm{~mol})$ and ethyl iodide $(0.7 \mathrm{ml}$, $0.008 \mathrm{~mol})$ was refluxed in $(50 \mathrm{ml})$ absolute ethanol in the presence of anhydrous sodium acetate $(2 \mathrm{~g})$ for 3 hours The organic layer was separated and slow evaporates to give green solid which was washed with warm water and then filtered off, dried and then recrystallized from ethanol to give 4 as green crystals m.p. $310-311^{\circ} \mathrm{C}$ (yield $64 \%$ ). IR ( $v$ $\left.\mathrm{cm}^{-1}\right): 3127(\mathrm{NH}), 1680(\mathrm{C}=\mathrm{O}) .{ }^{1} \mathrm{HNMR}\left(\mathrm{DMSO}^{-\mathrm{d}_{6}}\right): \delta$ 12.4(s, $1 \mathrm{H}, \mathrm{NH}$, exchangeable with $\left.\mathrm{D}_{2} \mathrm{O}\right), 8.6\left(\mathrm{~s}, 1 \mathrm{H}, \mathrm{C}_{6}-\mathrm{H}\right)$, 8.3-7.1(m, 9H $\left.\mathrm{H}_{\text {arom }}\right), 3.9(\mathrm{~s}, 3 \mathrm{H}, \mathrm{OMe}), 3.15(\mathrm{q}, 2 \mathrm{H}$, $\left.\mathrm{SCH}_{2} \mathrm{CH}_{3}\right), 1.36\left(\mathrm{t}, 3 \mathrm{H}, \mathrm{SCH}_{2} \underline{\mathrm{CH}}_{3}\right)$. MS m/z (\%): $389\left(\mathrm{M}^{+}\right.$, 18), 361 (100), 360 (77), 344 (18), 302 (7), 181 (17). Anal. Calcd. For $\mathrm{C}_{22} \mathrm{H}_{19} \mathrm{~N}_{3} \mathrm{O}_{2} \mathrm{~S}$ (389): C, 67.87; H, 4.88; N, 10.80; S, 8.23, Found: C, 67.73; H, 4.80; N, 10.66; S, 8.12.

2-Hydrazinyl-5-(4-methoxyphenyl)-7-phenylpyrido[2,3-d] pyrimidin-4(3H)-one 5

Method 1

Compound 1 (3.6 g, $0.01 \mathrm{~mol})$ was refluxed with hydrazine hydrate $(80 \%)(1.25 \mathrm{ml}, 0.025 \mathrm{~mol})$ in ethanol $(20 \mathrm{ml})$ for 2 hours. The solid deposited on hot was filtered off, dried and then recrystallized from dimethylformamide to give 5 as green crystals, m.p. $275-277^{\circ} \mathrm{C}$ (yield $39.6 \%$ ).

Method 2

Compound $4(1 \mathrm{~g}, 0.0025 \mathrm{~mol})$ was refluxed with excess hydrazine hydrate $(80 \%)$ in ethanol $(20 \mathrm{ml})$ for 2 hours. The 
solid deposited during the reflux was filtered off, dried and recrystallized from dimethylformamide to give 5 (yield 56.6\%); IR $\left(v \mathrm{~cm}^{-1}\right)$ : 3350, $3196\left(\mathrm{NH}_{2}\right), 1662(\mathrm{C}=\mathrm{O})$. ${ }^{1}$ HNMR (DMSO-d $\mathrm{d}_{6}$ ): $\delta \quad 10.3$ (br.s, $1 \mathrm{H}, \mathrm{NH}$, exchangeable with $\mathrm{D}_{2} \mathrm{O}$ ), $8.6\left(\mathrm{~s}, 1 \mathrm{H}, \mathrm{C}_{6}-\mathrm{H}\right), 8.3$ (br.s, $3 \mathrm{H}, \mathrm{NHNH}_{2}$, exchangeable with $\left.\mathrm{D}_{2} \mathrm{O}\right), 8.1-7.1\left(\mathrm{~m}, 9 \mathrm{H}_{\text {arom }}\right), 3.9(\mathrm{~s}, 3 \mathrm{H}$, $\mathrm{OMe})$. MS m/z (\%): $359\left(\mathrm{M}^{+}, 100\right), 358(40), 329$ (31), 300 (7). Anal. Calcd. For $\mathrm{C}_{20} \mathrm{H}_{17} \mathrm{~N}_{5} \mathrm{O}_{2}$ (359): C, 66.85; H, 4.74; $\mathrm{N}, 19.50$, Found: C, 66.68; H, 4.71; N, 19.32 .

6-(4-Methoxyphenyl)-8-phenylpyrido[2,3-d]-1,2,4-triazolo [4,3-a]-pyrimidin-5-one 6

Compound $5(1 \mathrm{~g}, 0.003 \mathrm{~mol})$ was refluxed with triethylorthformate $(10 \mathrm{ml})$ in the presences of acetic anhydride $(5$ $\mathrm{ml}$ ) for 16 hours. The reaction mixture was allowed to cool, and the obtained solid was filtered off, washed with petroleum ether $80-100^{\circ} \mathrm{C}$, dried and recrystallized from ethanol to give 6 as buff crystals, m.p. $300^{\circ} \mathrm{C}$ (yield $80 \%$ ). IR ( $v$ $\left.\mathrm{cm}^{-1}\right): 3120(\mathrm{NH}), 1714(\mathrm{C}=\mathrm{O}) .{ }^{1} \mathrm{HNMR}\left(\mathrm{DMSO}-\mathrm{d}_{6}\right): \delta 8.7$ (s, $\left.1 \mathrm{H}, \mathrm{C}_{7}-\mathrm{H}\right), 8.4-7.2$ (m, 9 $\mathrm{H}_{\text {arom }}$ ), 7.0 (br.s, $1 \mathrm{H}, \mathrm{NH}$, exchangeable with $\left.\mathrm{D}_{2} \mathrm{O}\right), 6.1\left(\mathrm{~s}, 1 \mathrm{H}, \mathrm{C}_{3}-\mathrm{H}\right), 3.9(\mathrm{~s}, 3 \mathrm{H}, \mathrm{OMe})$. MS m/z (\%): 369 (M $\left.\mathrm{M}^{+}, 100\right), 368$ (67), 342 (18), 327 (12). Anal. Calcd. For $\mathrm{C}_{21} \mathrm{H}_{15} \mathrm{~N}_{5} \mathrm{O}_{2}$ (369): C, 68.29; H, 4.04; N, 18.97, Found: C, 68.15; H, 4.29; N, 18.78.

6-(4-Methoxyphenyl)-8-phenyl-1H,2H-pyrido[2,3-d]-1,2,4triazolo[4,3-a]-pyrimidin-3,5-dione 8

A mixture of $5(1 \mathrm{~g}, 0.003 \mathrm{~mol})$, ethyl chloroformate (5 $\mathrm{ml})$ and pyridine $(20 \mathrm{ml})$ was refluxed for 6 hours. The reaction mixture was poured into water to give light brown solid which filtered off, dried and then recrystallized from ethanol to give 8 as yellow crystals, m.p. $228-230^{\circ} \mathrm{C}$ (yield $50 \%)$. IR $\left(\mathrm{v} \mathrm{cm}^{-1}\right): 3256(\mathrm{NH}), 1731,1706(2 \mathrm{C}=\mathrm{O}) .{ }^{1} \mathrm{HNMR}$ $\left(\right.$ DMSO-d $\left._{6}\right): \delta 8.6\left(\mathrm{~s}, 1 \mathrm{H}, \mathrm{C}_{7}-\mathrm{H}\right), 8.3-7.0\left(\mathrm{~m}, 9 \mathrm{H}_{\text {arom }}\right), 6.0$ (br.s, $2 \mathrm{H}, 2 \mathrm{NH}$, exchangeable with $\left.\mathrm{D}_{2} \mathrm{O}\right), 3.9(\mathrm{~s}, 3 \mathrm{H}, \mathrm{OMe})$. MS m/z (\%): 385 (M $\left.\mathrm{M}^{+}, 100\right), 342$ (15), 328 (17), $286(20)$. Anal. Calcd. For $\mathrm{C}_{21} \mathrm{H}_{15} \mathrm{~N}_{5} \mathrm{O}_{3}$ (385): C, 65.45; H, 3.90; N, 18.18, Found: C, 65.48; H, 4.01; N, 18.33.

6-(4-Methoxyphenyl)-8-phenyl-3-thioxo-1H,2H-pyrido [2,3-d]-1,2,4-triazolo[4,3-a]-pyrimidin-5-one 9

A mixture of $5(0.6 \mathrm{~g}, 0.0017 \mathrm{~mol})$ and phenyl isothiocyanate $(0.4 \mathrm{ml}, 0.003 \mathrm{~mol})$ was refluxed in pyridine $(15$ $\mathrm{ml}$ ) for 8 hours. The reaction mixture was poured onto ice/hydrochloric acid. The solid obtained was filtered off, dried and then recrystallized from benzene to give 9 as pink crystals, m.p. $110-112^{\circ} \mathrm{C}$ (yield $\left.35 \%\right)$. IR $\left(v^{-1}\right)$ : 3381 $(\mathrm{NH}, \quad$ broad $), 1676 \quad(\mathrm{C}=\mathrm{O}), 1246 \quad(\mathrm{C}=\mathrm{S}) .{ }^{1} \mathrm{HNMR}$ $\left(\mathrm{DMSO}_{-} \mathrm{d}_{6}\right): \delta 8.7\left(\mathrm{~s}, 1 \mathrm{H}, \mathrm{C}_{7}-\mathrm{H}\right), 8.1-7.2\left(\mathrm{~m}, 9 \mathrm{H}_{\text {arom. }}\right), 6.0$ (br.s, $2 \mathrm{H}, 2 \mathrm{NH}$, exchangeable with $\left.\mathrm{D}_{2} \mathrm{O}\right), 3.9(\mathrm{~s}, 3 \mathrm{H}, \mathrm{OMe})$. MS m/z (\%): $369 \quad\left(\mathrm{M}^{+}-\mathrm{S}, \quad 100\right)$. Anal. Calcd. For $\mathrm{C}_{21} \mathrm{H}_{15} \mathrm{~N}_{5} \mathrm{O}_{2} \mathrm{~S}$ (401): C, 62.84; H, 3.74; N, 17.46; S, 7.98, Found: C, 62.70; H, 3.91; N, 17.25; S, 8.18.

3-Methyl-6-(4-methoxyphenyl)-8-phenylpyrido[2,3-d]-1,2, 4-triazolo[4,3-a]pyrimidin-5(1H)-one 10

Compound 5 (1 g, $0.003 \mathrm{~mol})$ was refluxed in acetic anhydride $(10 \mathrm{ml})$ for 6 hours. The reaction mixture was poured onto ice/water. The yellow solid obtained was filtered off, dried and recrysytallized from methanol to give
10 as yellow crystals, m.p. $260-261^{\circ} \mathrm{C}$ (yield $72 \%$ ). IR ( $v$ $\left.\mathrm{cm}^{-1}\right): 3317(\mathrm{NH}), 1699(\mathrm{C}=\mathrm{O}) .{ }^{1} \mathrm{HNMR}\left(\mathrm{DMSO}^{-} \mathrm{d}_{6}\right): \delta 8.6$ (s, $\left.1 \mathrm{H}, \mathrm{C}_{7}-\mathrm{H}\right), 8.1-7.2\left(\mathrm{~m}, 9 \mathrm{H}_{\text {arom }}\right), 7.1$ (br.s, $1 \mathrm{H}, \mathrm{NH}$, exchangeable with $\left.\mathrm{D}_{2} \mathrm{O}\right), 3.8(\mathrm{~s}, 3 \mathrm{H}, \mathrm{OMe}), 2.3\left(\mathrm{~s}, 3 \mathrm{H}, \mathrm{C}_{3}-\mathrm{Me}\right)$. MS m/z (\%): $383\left(\mathrm{M}^{+}, 100\right), 382$ (54), 368 (19), 342 (22). Anal. Calcd. For $\mathrm{C}_{22} \mathrm{H}_{17} \mathrm{~N}_{5} \mathrm{O}_{2}$ (383): C, 68.93; H, 4.44; N, 18.28, Found: C, $69.11 ; \mathrm{H}, 4.62 ; \mathrm{N}, 18.08$.

10-Phenyl-3-Methyl-8-(4-methoxyphenyl)-5-(substituted)-7 -oxo-1H-pyrido[2,3-d]pyrimido[2,1-c][1,2,4]triazepine 11a, $\mathrm{b}$

A mixture of $5(1 \mathrm{~g}, 0.003 \mathrm{~mol})$ with acetyl acetone $(0.3$ $\mathrm{ml}, 0.003 \mathrm{~mol})$ and/or benzoyl acetone $(0.48 \mathrm{~g}, 0.003 \mathrm{~mol})$ in dimethylformamide $(30 \mathrm{ml})$ was refluxed for 8 hours. The reaction mixture poured onto water. The organic layer was extracted with methylene chloride, dried over magnesium sulfate and slow evaporated to give $11 \mathrm{a}$ and $11 \mathrm{~b}$, respectively.

11a: recrystallized from toluene as buff crystals, m.p. $150-152^{\circ} \mathrm{C}$ (yield 69\%). IR $\left(\mathrm{vcm}^{-1}\right): 3312(\mathrm{NH}), 1698$ $(\mathrm{C}=\mathrm{O}) .{ }^{1} \mathrm{HNMR}\left(\mathrm{DMSO}-\mathrm{d}_{6}\right): \delta 10.4(\mathrm{~s}, 1 \mathrm{H}, \mathrm{NH}$, exchangeable with $\left.\mathrm{D}_{2} \mathrm{O}\right), 8.2-6.9\left(\mathrm{~m}, 10 \mathrm{H}_{\text {arom }}+\mathrm{C}_{9}-\mathrm{H}\right), 6.1(\mathrm{~s}, 1 \mathrm{H}$, $\left.\mathrm{C}_{4}-\mathrm{H}\right), 3.8(\mathrm{~s}, 3 \mathrm{H}, \mathrm{OMe}), 2.9(\mathrm{~s}, 3 \mathrm{H}, \mathrm{Me}), 2.27(\mathrm{~s}, 3 \mathrm{H}$, $\mathrm{C}_{5}$-Me). MS m/z (\%): 423 (M+, 98), 422 (100), 408 (27), 329 (18). Anal. Calcd. For $\mathrm{C}_{25} \mathrm{H}_{21} \mathrm{~N}_{5} \mathrm{O}_{2}$ (423): C, 70.92; $\mathrm{H}$, 4.96; N, 16.55, Found: C, 70.80; H, 4.92; N, 16.80.

11 b: recrystallized from ethanol as green crystals, m.p. 250-251 ${ }^{\circ} \mathrm{C}$ (yield 58\%). IR $\left(v \mathrm{~cm}^{-1}\right): 3368(\mathrm{NH}), 1697$ $(\mathrm{C}=\mathrm{O}) .{ }^{1} \mathrm{HNMR}\left(\mathrm{DMSO}_{-} \mathrm{d}_{6}\right): \delta 10.3(\mathrm{~s}, 1 \mathrm{H}, \mathrm{NH}$, exchangeable with $\left.\mathrm{D}_{2} \mathrm{O}\right), 8.2-7.3\left(\mathrm{~m}, 14 \mathrm{H}_{\text {arom }}\right), 6.9\left(\mathrm{~s}, 1 \mathrm{H}, \mathrm{C}_{9}-\mathrm{H}\right), 6.1$ (s, $\left.1 \mathrm{H}, \mathrm{C}_{4}-\mathrm{H}\right), 3.6(\mathrm{~s}, 3 \mathrm{H}, \mathrm{Me}), 3.8(\mathrm{~s}, 3 \mathrm{H}, \mathrm{OMe}) . \mathrm{MS} \mathrm{m} / \mathrm{z}$ (\%): 485 (M+, 59), 383 (100), 329 (61), 328 (65), 314 (30), 300 (24). Anal. Calcd. For $\mathrm{C}_{30} \mathrm{H}_{23} \mathrm{~N}_{5} \mathrm{O}_{2}$ (485): C, 74.22; $\mathrm{H}$, 4.74; N, 14.43, Found: C, 74.20; H, 4.70; N, 14.29.

6-(4-Methoxyphenyl)-8-phenylpyrido[2,3-d]tetrazolo[1,5-a] pyrimidin-5 $(1 \mathrm{H})$-one 12

Compound $5(1 \mathrm{~g}, 0.003 \mathrm{~mol})$ was dissolved in $(10 \mathrm{ml})$ concentrated hydrochloric acid and then $(7 \mathrm{ml})$ of sodium nitrite $(10 \%)$ was added dropwise with stirring over a period of 2 hours at $0^{\circ} \mathrm{C}$. The obtained yellow solid was filtered off, dried and then recrystallized from ethanol to give 12 as yellow crystals, m.p. $230-232^{\circ} \mathrm{C}$ (yield $39 \%$ ). IR ( $v$ $\left.\mathrm{cm}^{-1}\right): 3384(\mathrm{NH}), 1700(\mathrm{C}=\mathrm{O}) .{ }^{1} \mathrm{HNMR}\left(\mathrm{DMSO}_{-} \mathrm{d}_{6}\right): \delta 8.5$ (s, $\left.1 \mathrm{H}, \mathrm{C}_{7}-\mathrm{H}\right), 7.8-7.0\left(\mathrm{~m}, 9 \mathrm{H}_{\text {arom }}\right), 5.4$ (br.s, $1 \mathrm{H}, \mathrm{NH}$, exchangeable with $\left.\mathrm{D}_{2} \mathrm{O}\right) 3.9(\mathrm{~s}, 3 \mathrm{H}, \mathrm{OMe})$. $\mathrm{MS} \mathrm{m} / \mathrm{z}(\%): 370$ $\left(\mathrm{M}^{+}\right.$, 37), 369 (100), 344 (42), 329 (22). Anal. Calcd. For $\mathrm{C}_{20} \mathrm{H}_{14} \mathrm{~N}_{6} \mathrm{O}_{2}$ (370): C, 64.86; H, 3.78; N, 22.70, Found: C, $65.03 ; \mathrm{H}, 3.70 ; \mathrm{N}, 22.53$.

\section{REFERENCES}

[1] M.R. Mahmoud, E.A.A. El-Bordany, N.F. Hassan, and F.S.M. Abu El-Azm, J. Phosphorus, Sulfur and Silicon and related elements, 2007, 182, 2507-2521

[2] J.A. Al-Masoudi, Y.A. Al-Soud, N.J. Al-Salihi, and N.A. 
M. R. Mahmoud et al:: Synthesis and Spectral Characterization of Novel Pyridotriazolo-, Pyridothiazolo-, Pyridotetrazolopyrimidines and Pyridopyrimidotriazepine Derivatives for Potential Pharmacological Activities

Al-Masoudi, Chem. Heterocycl Compd., 2006, 42, $1377-1404$

[3] G. Fischer, Adv. Heterocycl Chem., 2008, 95, 143-219

[4] J.G. Haasnoot, Coord. Chem. Rev., 2000, 200-202, 131-185

[5] N.D. Obushak, N.T. Pokhodylo, I.I. Krupa, and V.S. Matiichuk, Russian J. Org. Chem., 2007, 43(8), 1223-1227

[6] S.A. El-Assiery, G.H. Sayed, and A. Fouda, Acta. Pharm., 2004, 54, 143-150

[7] F.E. Goda, and F.A. Badria, Saudi. Pharm. J., 2005, 13, 2-3, $65-73$

[8] H. Moustafa. M.F. Shibl, and R. Hilal, J. Phosphorus, Sulfur and Silicon, 2005, 180(2), 459-478

[9] A.C. Valentin, E.S. Ayacheslav, A.G. Ekaterina, M.D. Sergey, and I.M. Valadimir, Collect Gzech. Chem. Commun., 2005, 70(3), 350-360

[10] J.W. Ellingboe, US Pat. 5466692 [C. A., 1996, 124, $176134 q]$

[11] M.R. Mahmoud, E.A.A. El-Bordany, M. E. Azab, and E. A. Soliman, J. Phosphorus, Sulfur and Silicon and related elements., 2007, 181, 1275-1289

[12] M.R. Mahmoud, E.A.A. El-Bordany, N.F. Hassan, and F.S.M.
Abu El-Azm, J. Chem. Res., 2007, 9, 541-544

[13] M.R. Mahmoud, H.M.F. Madkour, E.A.A. El-Bordany, and E. A. Soliman, J. Chem. Res, 2007, 673-676

[14] M.M. Kamel, Z.M. Nofal, W.A. Zaghary, M.R. Mahmoud, and N.S. Ismail, Egypt J. Chem., 2007, 50(3), 369-390

[15] M.R. Mahmoud, M.M. El-Shahawi, and S.E. Farahat, J. Chem. Res., 2008, 59-60

[16] M.R. Mahmoud, M.M. El-Shahawi, and S.E. Farahat, J. Chem. Res., 2008, 86-88

[17] M.R. Mahmoud, M.M. El-Shahawi, E.A.A. El-Bordany, and F.S.M. Abu El-Azm, J. Chem. Res., 2008, 609-612.

[18] M.R. Mahmoud, H.M.F. Madkour, E.A.A. El-Bordany, and E. A. Soliman, J. P, S, Si and related elements, 2009, 184(1), $1-8$

[19] M.R. Mahmoud, F.A. El-Bassiouny, M.E. Azab, M.Y. El-Kady, and H.M. Rashed, J. Chem. Res., 2009, 41-45

[20] M.R. Mahmoud, and H.A.Y. Derbala, Synth. Commun., 2010, 40, 1516-1529

[21] M.R. Mahmoud, M.M. El-Shahawi, E.A.A. El-Bordany, and F.S.M. Abu El-Azm, Europen J. Chem., 2010, 1(2), 134-139 